\title{
Ocular Filariasis in Human Caused by Breinlia (Johnstonema) annulipapillata Nematode, Australía
}

Anson V. Koehler, Jennifer M.B. Robson, David M. Spratt, Joshua Hann, lan Beveridge, Michael Walsh, Rodney McDougall, Mark Bromley, Anna Hume, Harsha Sheorey, Robin B. Gasser

We report a human case of ocular filariasis, caused by a species of Breinlia nematode, from Queensland, Australia. Morphological and molecular evidence indicated that the nematode Breinlia (Johnstonema) annulipapillata, or a closely related taxon, likely transmitted from a macropodid marsupial host was involved, which might represent an accidental finding or an emerging zoonosis.

F ilariasis of the eye is commonly caused by adults or larvae of the filarioid nematodes Onchocerca volvulus, Loa loa, and Dirofilaria immitis (1), although sporadic cases involving Acanthocheilonema, Loaina $(1,2)$, or Pelecitus (3) nematodes have been reported. Filarioids in eyes are challenging to identify morphologically to genus or species, because often only single, immature worms of 1 sex are present, the worms are degraded, or both (2). Molecular tools can generally improve the identification of worms of the eyes (e.g., Dirofilaria hongkongensis [4]), even if only to genus (e.g., Pelecitus sp. [3]). In Australia, D. immitis nematodes have typically been the causative agent of ocular filariasis infection in humans; the prevalence of dirofilariasis in dogs was historically quite high (up to $64 \%$ ) in the subtropical and tropical climes, such as around Brisbane (5). We report a human case of an ocular infection by a Breinlia sp. nematode commonly found in Australian marsupials and rodents.

Author affiliations: The University of Melbourne, Parkville, Victoria, Australia (A.V. Koehler, I. Beveridge, R.B. Gasser); Sullivan Nicolaides Pathology, Brisbane, Queensland, Australia (J.M.B. Robson, M. Walsh, R. McDougall, M. Bromley, A. Hume); Australian National Wildlife Collection, Commonwealth Scientific and Industrial Research Organisation, Canberra, Australian Capital Territory, Australia (D.M. Spratt); Eastside Eye Specialist Care, Carindale, Queensland, Australia (J. Hann); St. Vincent's Hospital, Melbourne, Victoria, Australia (H. Sheorey)

DOI: https://doi.org/10.3201/eid2701.203585

\section{The Study}

In May 2019, a 73-year-old man in Brisbane, Queensland, Australia came to his optometrist with an irritated right eye and eyelid. Entropion was suspected, although the patient was unable to tolerate a thorough examination because of extreme irritation of the involved eye. He was referred to an ophthalmologist 3 weeks later; the eye was still irritated, but not grossly inflamed or red. Slit lamp examination revealed a motile nematode in the subconjunctiva (Figure 1; Video, https:/ / wwwnc.cdc.gov/EID/ article/27/1/20-3585-V1.htm), which was extracted and fixed in neutral-buffered formalin. Initial morphological examination of the specimen revealed a male filarioid (17-20 mm long) with short, heavily sclerotized spicules; the right spicule had a bifid distal extremity, highly suggestive of Breinlia (Johnstonema) annulipapillata (Figure 1).

The patient was born in Poland and immigrated to Melbourne in 1969, where he spent his working life before retiring to Brisbane in 2005. He had no pets or close contact with animals. His only recent travel was to the Gold Coast and to an island in Moreton Bay, both near Brisbane. The patient had no noteworthy medical history apart from hyperthyroidism, which was well controlled. C-reactive protein (CRP) and full blood count (FBC) test results were within reference ranges, with no eosinophilia, and results of filarial serologic testing (IgG enzyme immunoassay using antigen Bm14) were negative. After the nematode was removed from the patient's eye, symptoms resolved. No anthelmintic medication was prescribed.

We extracted genomic DNA from the formalinfixed paraffin-embedded worm using a GeneRead DNA FFPE kit (QIAGEN, https://www.qiagen. com) and then subjected it to PCR, targeting the small subunit of nuclear ribosomal RNA gene 

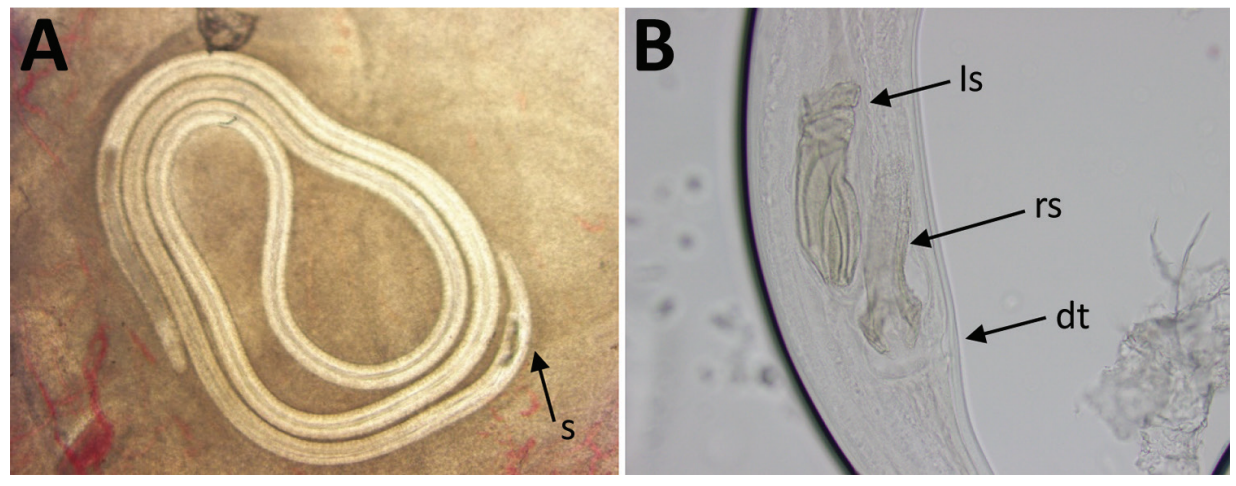

Figure 1. Identification of Breinlia sp. nematodes from a patient with ocular filariasis, Brisbane, Queensland, Australia, 2019. A) Photograph (in situ) of male $B$. (Johnstonema) annulipapillata nematode from the subconjunctiva, illustrating thick heavily sclerotized spicules (s). B) Right lateral view of male tail of $B$. (J.) annulipapillata nematode, illustrating left (Is) and right (rs) spicules; right spicules showed a bifurcated distal extremity (dt), a diagnostic character of the species.

(SSU), and a nested PCR, targeting the mitochondrial cytochrome c oxidase subunit 1 gene (cox-1) (Table; 6). Known positive (Onchocerca volvulus DNA) and no-template controls were included. Amplicons were sequenced using an established protocol (8).

We assessed the sequences (GenBank accession nos. MT752937 [SSU, 724 bp] and MT754705 [cox-1, $660 \mathrm{bp}]$ ) for quality and compared them with those available publicly. Because sequence data for $S S U$, cox -1 , or both were publicly available for only 3 taxa of 24 known species of Breinlia - B. mundayi from the swamp wallaby (Wallabia bicolor); Breinlia sp. from a Leadbeater's possum (Gymnobelideus leadbeateri); and B. jittapalapongi from an Asian house rat (Rattus tanezumi) - molecular identification was limited to these taxa. The SSU sequence (724 bp) obtained for the worm under investigation was $99 \%$ similar to those of B. mundayi (GenBank accession no. JF934735; 708/710 bp), Breinlia sp. from an opossum (GenBank accession no. MT731343; 711/712 bp), and B. jittapalapongi (GenBank accession no. KP760119; 656/665 bp). The cox-1 sequence (660 bp) obtained was $92 \%$ similar to that of B. jittapalapongi (GenBank accession no. KP760170; 553/604 bp) and 91\% similar to that of Breinlia sp. from the opossum (GenBank accession no. MT724666; 601/659 bp); no cox-1 sequence was publicly available for $B$. mundayi.
The sequences obtained were aligned to those accessible publicly for $34(S S U)$ or 29 (cox-1) species of filarioid and of Mastophorus muris (outgroup) (Figure 2). Aligned SSU and cox-1 sequence data were subjected to separate phylogenetic analyses using the Bayesian inference method (8), with nodal support values given as posterior probabilities. The resultant trees (Figure 2) revealed that the nematode under study is a member of the genus Breinlia, as it grouped with Breinlia from the opossum, B. mundayi (SSU only), and B. jittapalapong $i$ with strong statistical support. Thus, this worm could be identified molecularly as a Breinlia sp.; it could not be identified to species because of the lack of sequence data for Breinlia spp. in public databases.

There are 5 reports of human intraocular filariasis from Australia: 4 suspected D. immitis cases from New South Wales, Queensland, and Victoria (9-12); and 1 Dipetalonema (Acanthocheilonema) reconditum case from Victoria (13). The short, heavily sclerotized spicules of this specimen, with a bifid distal extremity on the right spicule (Figure 1), indicated that it was neither of these taxa, but rather B. (J.) annulipapillata. This species occurs in a range of macropodid species, predominantly in northern Australia, although it is also found in swamp wallabies in the south. The nematodes of only other known species of the subgenus Johnstonema, B. (J.) woerlei, has much

\begin{tabular}{|c|c|c|c|c|c|}
\hline Designation & Primer pair & Oligonucleotide sequence, $5^{\prime} \rightarrow 3^{\prime}$ & $\begin{array}{l}\text { Annealing temperature, } \\
{ }^{\circ} \mathrm{C} \text { (time) } \dagger\end{array}$ & $\begin{array}{l}\text { Expected } \\
\text { size, bp }\end{array}$ & Reference \\
\hline \multicolumn{6}{|l|}{ SSU } \\
\hline $1^{\circ} \mathrm{PCR}$ & $\begin{array}{l}\text { F18ScF1 } \\
\text { F18ScR1 }\end{array}$ & $\begin{array}{l}\text { ACCGCCCTAGTTCTGACCGTAAA } \\
\text { GGTTCAAGCCACTGCGATTAAAGC }\end{array}$ & $58(45 s)$ & 830 & (6) \\
\hline \multicolumn{6}{|l|}{$\operatorname{cox}-1$} \\
\hline $1^{\circ} \mathrm{PCR}$ & $\begin{array}{l}\text { FCo1extdF1 } \\
\text { FCo1extdR1 }\end{array}$ & $\begin{array}{c}\text { TATAATTCTGTTYTDACTA } \\
\text { ATGAAAATGAGCYACWACATAA }\end{array}$ & $52(45 s)$ & 970 & (6) \\
\hline $2^{\circ} \mathrm{PCR}$ & $\begin{array}{l}\text { COlintF } \\
\text { COlintR }\end{array}$ & $\begin{array}{l}\text { TGATTGGTGGTTTTGGTAA } \\
\text { ATAAGTACGAGTATCAATATC }\end{array}$ & $52(45 s)$ & 650 & $(7)$ \\
\hline
\end{tabular}

* cox-1, cytochrome $c$ oxidase subunit 1; SSU small subunit of nuclear ribosomal RNA.

†All PCRs used 35 cycles with an initial denaturation at $94^{\circ} \mathrm{C}$ for $5 \mathrm{~min}$, all subsequent denaturation cycles were $30 \mathrm{~s}$, and all extensions were 1 min. 


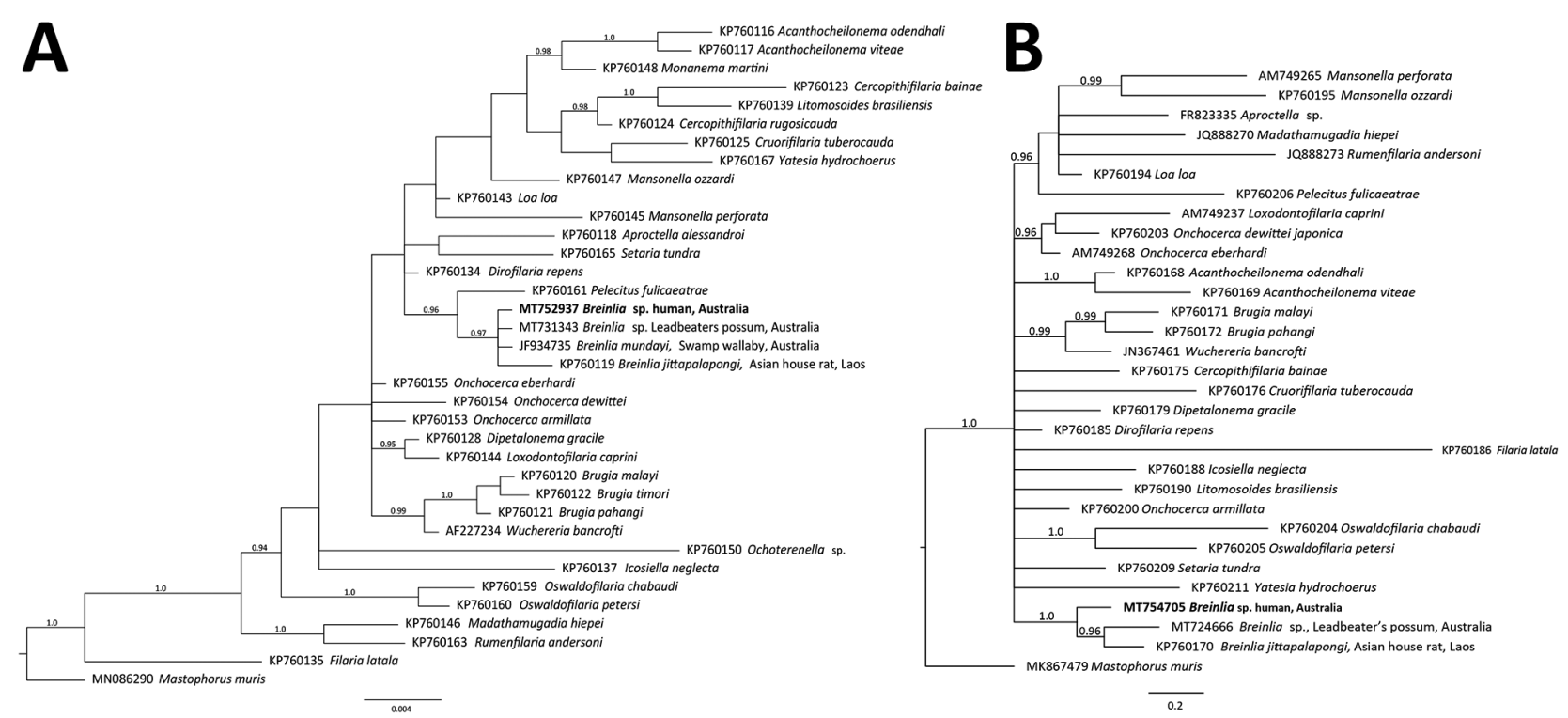

Figure 2. Relationship of the novel Breinlia sp. taxon (bold type), the nematode species recovered from the eye of a human patient with ocular filariasis, Brisbane, Queensland, Australia, 2019, with representative sequences from members of the family Onchocercidae based on phylogenetic analysis. A) Small subunit of nuclear ribosomal RNA gene; B) cytochrome oxidase 1 gene. Data were compiled using the Bayesian inference method. Branch support given in posterior probability. Respective sequences for Mastophorus muris (outgroup) were included in the analyses. GenBank accession numbers are provided. Scale bars represent expected substitutions per site.

larger, heavily sclerotized spicules, but without a bifid extremity on the right spicule, and occurs in the short-eared rock wallaby (Petrogale brachyotis) in the Northern Territory (14).

Although no life cycles of subgenus Johnstonema nematodes are known, those of 4 species of the subgenus Breinlia are known and involve Aedes mosquitoes as intermediate hosts (14). The patient was probably been bitten by the intermediate host of this filarioid, possibly a mosquito, that had previously taken a blood meal from a macropodid and was carrying infective larval stages (L3s). Once in the patient, the L3s would have undergone 2 additional molts and established themselves in the eye and perhaps in other tissues throughout the body (although there was no evidence of infection elsewhere). Adult Breinlia nematodes are found predominantly in the peritoneal and pleural cavities of mammalian definitive hosts (14). However, other filarial nematodes have a tropism for the eye, and several cases have been reported of zoonotic filariasis of the eye relating to Dirofilaria sp. nematodes (1). Breinlia nematodes had not been found previously in humans, but $B$. sergenti nematodes has been recorded in the slow loris (Nycticebus coucang) in Southeast Asia (14). It is possible that ocular Breinlia infections may go undetected in humans, particularly in less conspicuous places than the eye, and may be more common than expected in areas where Breinlia-infected marsupials are prevalent.

\section{Conclusions}

This human case of ocular filariasis caused by Breinlia sp. nematodes is highly unusual and was likely transmitted from a kangaroo or wallaby via a bloodfeeding intermediate host, possibly a mosquito, to the patient. Microscopic identification of filarioids can be challenging, depending on their stage of development and sex, but fortuitously that was not the case here. Nevertheless, the use of the current molecular approach can be advantageous for generic or specific identification, provided that sufficient sequence data are available in public databases. We recommend that both morphological and molecular tools be used to attempt to achieve a specific diagnosis in cases of human ocular filariasis.

This study was partially supported through a grant from the Australian Research Council (grant no. LP160101299 to R.B.G. and A.V.K.).

\section{About the Author}

Dr. Koehler is a molecular parasitologist in the Gasser Lab in the Department of Veterinary Biosciences at The University of Melbourne, Australia. His research interests include the phylogenetics and biology of parasites. 


\section{References}

1. Otranto D, Eberhard ML. Zoonotic helminths affecting the human eye. Parasit Vectors. 2011;4:41. https://doi.org/ 10.1186/1756-3305-4-41

2. Beaver PC. Intraocular filariasis: a brief review. Am J Trop Med Hyg. 1989;40:40-5. https://doi.org/10.4269/ ajtmh.1989.40.40

3. Bain O, Otranto D, Diniz DG, Nascimento dos Santos J, Pinto de Oliveira N, Frota de Almeida IN, et al. Human intraocular filariasis caused by Pelecitus sp. nematode, Brazil. Emerg Infect Dis. 2011;17:867-9. https:/ /doi.org/10.3201/ eid1705.101309

4. Winkler S, Pollreisz A, Georgopoulos M, Bagò-Horvath Z, Auer H, To KK-W, et al. Candidatus Dirofilaria hongkongensis as causative agent of human ocular filariosis after travel to India. Emerg Infect Dis. 2017;23:1428-31. https:/ / doi.org/ 10.3201/eid2308.170423

5. Orr B, Ma G, Koh WL, Malik R, Norris JM, Westman ME, et al. Pig-hunting dogs are an at-risk population for canine heartworm (Dirofilaria immitis) infection in eastern Australia. Parasit Vectors. 2020;13:69. https://doi.org/10.1186/ s13071-020-3943-4

6. Lefoulon E, Bain O, Bourret J, Junker K, Guerrero R, Cañizales I, et al. Shaking the tree: multi-locus sequence typing usurps current onchocercid (filarial nematode) phylogeny. PLoS Negl Trop Dis. 2015;9:e004233. https://doi.org/10.1371/journal.pntd.0004233

7. Casiraghi M, Anderson TJ, Bandi C, Bazzocchi C, Genchi C. A phylogenetic analysis of filarial nematodes: comparison with the phylogeny of Wolbachia endosymbionts. Parasitology. 2001;122:93-103. https://doi.org/10.1017/ S0031182000007149

8. Koehler AV, Haydon SR, Jex AR, Gasser RB. Cryptosporidium and Giardia taxa in faecal samples from animals in catchments supplying the city of Melbourne with drinking water (2011 to 2015). Parasit Vectors. 2016;9:315. https:/ / doi.org/10.1186/s13071-016-1607-1

9. Kerkenezov N. Intra-ocular filariasis in Australia. Br J Ophthalmol. 1962;46:607-15. https://doi.org/10.1136/ bjo.46.10.607

10. Moorhouse DE. Dirofilaria immitis: a cause of human intra-ocular infection. Infection. 1978;6:192-3. https:// doi.org/10.1007/BF01641909

11. Boreham RE, Cooney PT, Stewart PA. Dirofilariasis with conjunctival inflammation. Med J Aust. 1997;167:51. https://doi.org/10.5694/j.1326-5377.1997.tb138768.x

12. Chong EW, Sheorey H, Lo CH, Spratt DM, Graue-Hernández E. Subconjunctival dog heartworm. Med J Aust. 2010;193:184. https:// doi.org/10.5694/ j.1326-5377.2010.tb03845.x

13. Huynh T, Thean J, Maini R. Dipetalonema reconditum in the human eye. Br J Ophthalmol. 2001;85:1391-2. https://doi.org/10.1136/bjo.85.11.1384i

14. Spratt DM. New records of filarioid nematodes (Nematoda: Filarioidea) parasitic in Australasian monotremes, marsupials and murids, with descriptions of nine new species. Zootaxa. 2011;2860:1-61 https:/ / doi.org/10.11646/ zootaxa.2860.1.1

Address for correspondence: Anson Koehler, Department of Veterinary Biosciences, Melbourne Veterinary School, Faculty of Veterinary and Agricultural Sciences, The University of Melbourne, Corner of Park Drive and Flemington Road, Parkville, VIC 3010, Australia; email: anson.koehler@unimelb.edu.au

\section{EID Podcast A Critique of Coronavirus}

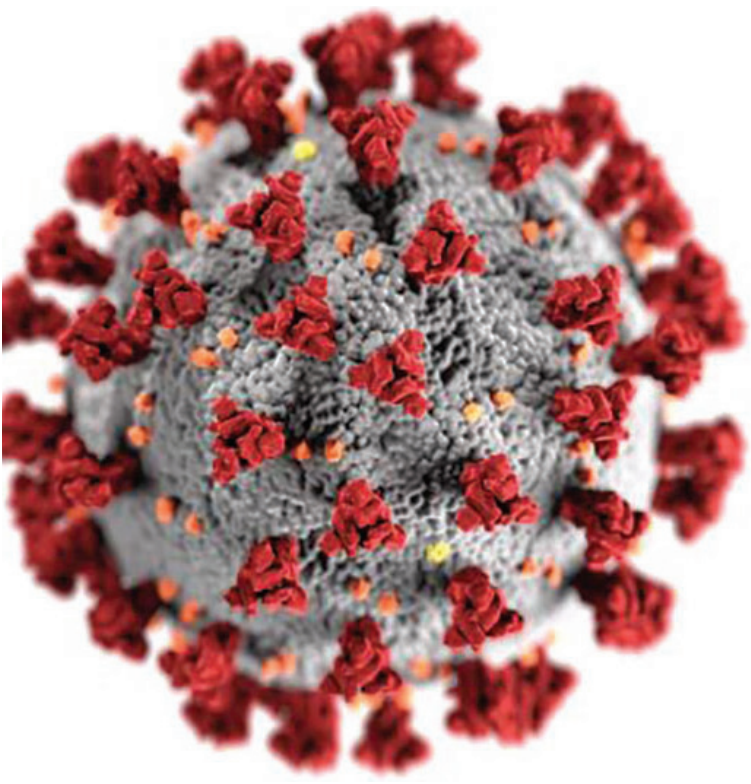

Humans have spent eons imagining-and experiencing-outbreaks of disease. Now that the COVID-19 pandemic has reached our doorstep, it's jarring to think about how this virus is eerily different from the pandemics of popular imagination.

In this EID podcast, Dr. Elana Osen, a specialty registrar at St. George's University Hospital in London, reads a poem she wrote about her experience of the COVID-19 pandemic.

\section{Visit our website to listen: https: / /go.usa.gov/xwjzs}

\section{EMERGING INFECTIOUS DISEASES}

